Meta

Journal des tradlucteurs

Translators' Journal

\title{
Oral Cloze: A Backup Exercise for Interpreting
}

\section{Graciela Anaya Dávila Garibi et Javier Lopez Islas}

Volume 35, numéro 3, septembre 1990

La traduction dans le monde hispanolusophone

URI : https://id.erudit.org/iderudit/002807ar

DOI : https://doi.org/10.7202/002807ar

Aller au sommaire du numéro

Éditeur(s)

Les Presses de l'Université de Montréal

ISSN

0026-0452 (imprimé)

1492-1421 (numérique)

Découvrir la revue

Citer cet article

Anaya Dávila Garibi, G. \& Lopez Islas, J. (1990). Oral Cloze: A Backup Exercise for Interpreting. Meta, 35(3), 647-651. https://doi.org/10.7202/002807ar d'utilisation que vous pouvez consulter en ligne.

https://apropos.erudit.org/fr/usagers/politique-dutilisation/ 


\title{
ORAL CLOZE: A BACKUP EXERCISE FOR INTERPRETING
}

\author{
Graciela ANAYA DÁvila GARIBI AND JAVIER LOPEZ ISLAS \\ Instituto Superior de Intérpretes y Traductores, Mexico
}

In Mexico, there are seven institutions which offer courses in translation at different levels: as an undergraduate degree at the Intercontinental University, the University of Nuevo Leon and the Instituto Superior de Interpretes y Traductores (ISIT); as a specialist subject at the Autonomous University of Queretaro and the National Autonomous University of Mexico; or as a diploma course at the Ibero-American University and the Colegio de México. The Instituto Superior de Intérpretes y Traductores is the only institution in Spanish America to offer an undergraduate degree course in interpreting.

Founded in 1966 in Mexico City, the ISIT has played an important role in training interpreters and translators. Since 1980, it has provided degree courses in interpreting and translation. These courses last four years and are officially recognized by the Mexican Public Education Secretariat. Since then, students seeking to be admitted to the ISIT have had to have completed their high school education, have complete command of the English language and are required to pass an entrance examination. Currently, thanks to the efforts of the Institute's director to improve academic standards in both degree courses, provisions are made in the study program for one-and-a-half years of joint studies, social service and the professional thesis which have to be completed by the students who wish to graduate as interpreters or translators.

\section{THE ENTRANCE EXAMINATION}

Generally speaking, the purpose of an entrance examination is to control admission to institutions and to see how equipped the applicant is in terms of knowledge and skill to be able to function efficiently in later professional life. In this case, the very nature of the tasks involved in interpreting and translation requires the student to possess special ability to understand both the spoken language and written texts. In 1980, a decision was made to divide the entrance examination into two parts consisting of a written examination and an oral examination so as to be able to assess different aspects of these skills. Up to 1985 , more importance was given to the written examination which was more thorough than the oral test and was made up of reading comprehension and grammar exercises in English. The oral examination consisted of a short interview lasting around five minutes. A new examination was designed in 1985 and this is the examination still being used to date.

The new appraisal system also consists of a two-part examination. The aim of the written part is to assess the candidate's reading comprehension, grammar and writing skills in a foreign language based on a text in English. More specifically, the candidate is tested in: a) reading comprehension by answering questions on the text; b) word recognition by indicating the morphological and syntactical classification of the words contained in a paragraph, by identifying words in a given context by finding a word that fits the meaning of a sentence in an incomplete text and by choosing synonyms for a given word list; and c) summarizing the original text. These exercises respond to the needs of the 
candidates in some cases to work with the text so as to become familiar with it and be able to leave it aside for some of the exercises.

The oral examination is made up of three exercises which are taped beforehand to eliminate problems of subjectivity and outside noises during the test. The oral tests are: a) shadowing in English to assess the candidate's ability to speak, pronounce correctly, and listen at the same time, repeating what is being said on the tape like an echo. eg.:

(Tape) ABUNDANCE HAS INFLUENCED AMERICAN LIFE IN

(candidate) abundance has influenced American life

MANY WAYS BUT THERE IS PERHAPS NO RESPECT IN WHICH

in (many) ways but there is perhaps no [aspect] in

THIS INFLUENCE HAS BEEN MORE PROFOUND THAN IN THE

which this influence has been [most] profound than

FORMING AND STRENGTHENING OF THE...

in the forming and (strengthening) of the...

The candidate is therefore required to speak quickly, identify sounds and correctly pronounce what he is hearing. Failing this, he is likely to make mistakes by skipping words (the words in parentheses), pronouncing words incorrectly (the words in square brackets), or by substituting synonyms; b) an exercise in aural comprehension in which the candidates are read a passage in English twice and then have to answer questions on it in writing; $c$ ) an oral Cloze test in Spanish so that the examiner can assess the candidate's ability to handle the syntaxis of an incomplete text.

This article concentrates on the analysis of the Cloze procedure and special attention is given to the transliteration of the written Cloze and the oral Cloze. So as to understand this analysis, we must briefly consider the characteristics of the Cloze procedure when used as a test and within the theoretical framework defending it.

\section{THE THEORETICAL FRAMEWORK}

The Cloze test was first designed in 1953 by Wilson Taylor and is based primarily on Gestalt's psychological theory of the "close" premise which supposes that Man has a tendency to complete incomplete forms. The task of the candidate sitting on a Cloze is to fill in blanks by guessing what the missing words could be. This procedure is a special type of "close" as the candidate is required to complete something which is incomplete. Originally, this test was only used to assess readability but later on, other studies showed that it could also be used for gauging reading comprehension. In 1979, however, John Oller, who was also researching the Cloze procedure, acknowledged that this type of test not only requires the candidate to be able to fill in the blanks as his linguistic knowledge is also involved. Oller calls this knowledge pragmatic expectancy grammar, which is based on the possibility of being able to partially predict what will follow in any sequence of linguistic elements, be these sounds, words, sentences, etc. Thus, the redundance of a language facilitates the task of filling in the missing words in the test so as to reconstruct the text's coherence.

Oller also maintains that the candidate has to use his short- and long-term memory in answering the test. Finally, devotees of the Cloze procedure affirm that it can be used to gauge vocabulary and, to a certain extent, creativity.

\section{THE CLOZE}

The Cloze procedure technique is very simple: first the examiner must choose a text of approximately 375 words in length from which he must delete words at regular 
intervals throughout. The deleted words must be blanked and the gaps must be the same size for each word. The candidate must insert a word in each space that fits the context syntactically and/or semantically.

There are several ways of carrying out the oral examination : as in all oral exams, the oral Cloze test used in the ISIT is based on a shorter text of around 160 words in length. Every tenth word is omitted which means that a total of fourteen words are left out (see annex 1). The text is read aloud twice and recorded. The space are indicated by ringing a bell. The candidate sitting the test must be given an answer sheet on which the words immediately before and after the blank are shown:

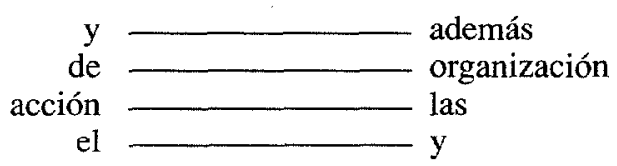

First, the candidate should just listen to the passage as it is read. On the second reading he has to fill in the gaps with a word when he hears the bell.

There are two ways of grading a Cloze test: some examiners only accept the exact word, or the word that was originally left out of the text (this is a "closed" Cloze test). Other examiners, however, accept any word that is grammaticaly acceptable, or a word that fits syntactically and/or semantically (this is the "open" Cloze procedure). The open Cloze is the form used at the ISIT.

\section{ANALYSIS}

The hypotheses for the differences between the written and oral Cloze tests are based on examinations taken at the ISIT from May-August, 1986.

Obviously, one of the main differences is that in the written test, the candidate has the text in front of him whereas in the oral test he does not. This means that the sense relied on in the written test is sight whilst hearing is the predominant sense in the oral test. In a written Cloze test, the candidate can consult the text as often as he wishes. In an oral Cloze, however, he must rely on his memory to reconstruct the overall meaning of the passage. In addition to the whole meaning of the text, in the written Cloze he can fall back on the syntactical-semantic context surrounding the blank when deciding on what word would fit. In the oral test, he has to base selection on the last word he heard which provides the syntactical-semantic guide to the context.

The following sentence is taken from the examination that was set and the omitted word is poner:

"... los gobiernos tomaron medidas para en ejecución las declaraciones emitidas por los Ministros..."

A variety of answers was given to fill in this blank. Since the word preceding the blank, para, is a preposition, it would be natural to expect a noun or a verb infinitive to follow, and some of the answers were: declarar, hacer, solucionar, realizar, mejorar, etc., or nouns such as el desarrollo, la solución, esos problemas. These terms are all possible since the candidates did not remember what came next in the passage and had to rely on what they remembered from what came before. These terms, however, would not be possible answers in a written Cloze test as the candidate's word selection would be considerably reduced by the presence of en ejecución.

Secondly, different rhythms are used in written and spoken language. Pauses in a written text are marked by punctuation whilst prosodic and paralinguistic factors determine 
rhythm in speech. Since these two forms of rhythm do not exactly coincide, when a text is read aloud the pauses corresponding to the punctuation are not always observed. Generally, the rule is that a full stop is given a longer pause than a comma in reading. However, everybody has their own way of doing this, and this means that in many cases our sense of hearing is not able to recognize the type of pause and thus interpret it. This was very clear from the tests carried out at the ISIT:

“... el 'nuevo diálogo' logró reactivar las relaciones entre la América Latina y los Estados Unidos; y (sirvió) además para demostrar la importancia y la necesidad ..."

The answers confirming the above were: el Medio Oriente, Canadá and Europa. The use of these words would imply that the candidates felt they were dealing with a list and that they failed to interpret the pause as a semi-colon. It is hard to say whether these answers were prompted because the pause was not correctly made when the text was read aloud or because the candidate gave the pause a different meaning.

A third difference lies in the candidate's relative freedom to select an appropriate word. The elements that make up a message are always linked together on the basis of combination and selection. It would appear that both linguistic operations are used in the written and oral Cloze exercises. The selection process for each type of exercise is different, however. In the written test, the candidate can grasp the whole meaning of the text and has time to think before selecting a word from his lexical repertoire (or paradigms) to fit the syntactical-semantic context. In the oral test, the candidate is restricted to the vocabulary available to him at that moment and his only limitation is the preceding context. For example:

"En (los) debates de la Asamblea General hubo críticas constructivas; los _ de los gobiernos señalaron que se trataba de ..."

The missing word in this paragraph is representantes. A wide range of words, however, such as partidarios, participantes, socios and individuos, etc., were suggested. It is less probable - but not impossible - that these words would have been selected in a written Cloze test.

\section{CONCLUSIONS}

Although linguists agree that there are differences between the written and spoken language, these have not been clearly identified. In this respect, analysis of the Cloze procedure shows that there are some important differences in: the message's materiality; grammar; rules; the use of different vocabulary; the scope of prosodic and paralinguistic factors in speech; problems of comprehension and perception depending on how the message is put across, etc. This study also confirms that the spoken word develops through time and disappears, whilst the written word is captured, preserved and made stable. Aural comprehension is an accumulative process which develops into formed ideas as the dialogue progresses - as more is said, the listener acquires knowledge depending on his short - and long-term memory.

On the other hand, the analysis of tests of this kind could come close to defining what interpreting and translation are. The terms "interpreter" and "translator" are often used without making a distinction between them since the objective of both professions is to communicate the message made in one language into another. However, the theoretical bases and practices involved in each are often unknown.

The development of oral/aural comprehension is very important in an interpreter's training, and interpreting schools undoubtedly use a wide variety of techniques to help the student recognize key words, listen and speak at the same time, improve his memory, 
etc. Likewise, the use of the Cloze procedure could be encouraged to back them up. Oral Cloze exercises could increase and reinforce some of the interpreter's special skills such as how to anticipate word meaning, how to handle the syntaxis of any specific text, how to improvise vocabulary, and to improve his memory, concentration and creativity.

\section{BIBLIOGRAPHY}

ANAYA D.G., Graciela (1987): "Implicaciones lingüísticas en el uso de la prueba Cloze oral", Conference given at the XX Round Table Meeting of the Sociedad Mexicana de Antropología, Mexico City, 26-31 October.

ANDERSON, Jonathan (1976): Psycholinguistic Experiments in Foreign Language Testing, St-Lucia, Queensland, University of Queensland Press.

JAKOBSON, ROMAN \& Morris HALLE (1973): Fundamentos del lenguaje, Madrid, Ed. Ayuso.

MALMBERG, Bertil (1974): Lingüística estructural y comunicación humana, Madrid, Gredos.

OLLER, John W. Jr. (1979): Language Tests at School; A Pragmatic Approach, London, Longman.

OLLER, John W. (ed.) (1983): Issues in Language Testing Research, Mass, Newbury House Publishers.

WELLER F., Georgeanne (1986): "Innovations in the Interpretation Program at the ISIT in Mexico City", in Newman, Patricia et al. (eds.), Proceedings of First North American Translators Congress, México, February 26-28, Medford, N.J., Learned Information Inc., pp. 231-233.

WILSON L., Taylor (1953): “Cloze Procedure, a New Tool for Measuring Readability", Journalism Quarterly, 30, pp. 415-433.

WILSON L., Taylor (1956): "Recent Developments in the Use of Cloze Procedure", Journalism Quarterly, 33 , pp. $42-48$, p. 99.

* Translated by: Gillian Glass, B.A.

\section{ANNEX 1}

ORAL CLOZE TEST IN SPANISH

INTRODUCCION AL INFORME ANUAL DEL SECRETARIO GENERAL DE LA O.E.A. EN 1974.

Durante el año 1974 el nuevo dialogo logró reactivar las relaciones entre la América Latina y los Estados Unidos; y _ (sirvió) además para demostrar la importancia y la necesidad de __ (la) organización regional en el proceso de traducir en acción (efectiva) las recomendaciones de cualquier foro empeñado en promover el _ (entendimiento) y la cooperación interamericanos. Es de esperar que los __ (obstáculos) que han surgido recientemente en el normal desarrollo de __(este) proceso sean subsanadas a la brevedad posible.

En la _ (Asamblea) General celebrada en Atlanta, los gobiernos tomaron medidas para _- (poner) en ejecución las declaraciones emitidas por los Ministros de__(Relaciones) Exteriores en las reuniones informales de Tlatelolco y Washington. _ (Se) recomendaron a la Secretaría General estudios de importancia sobre _ (la) escasez mundial de alimentos y las empresas transnacionales. En _ (los) debates de la Asamblea General hubo críticas constructivas; los __(representantes) de los gobiernos señalaron que se trataba de una _ _ (autocrítica) concerniente a la Organización como un cuerpo colectivo. 